UNIVERSITY
OF DEBRECEN

FACULTY OF

HEALTH

NYÍREGYHÁZA

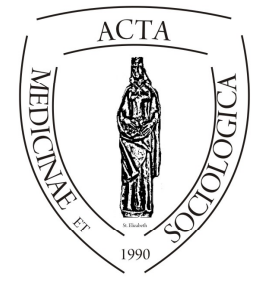

ACTA

MedSoc

VOLUME 3.

2013

\title{
Őszülő társadalmak: Aktív idősödés - nemzedékek közötti szolidaritás
}

\author{
Dr. Semsei Imre \\ Debreceni Egyetem, Egészségügyi Kar, \\ Gerontológiai Tudományos Koordinációs Központ
}

\begin{abstract}
Graying Societies: Active Aging - Solidarity between Generations.
Hungary, among other European nations, is a graying (aging) society characterized by all the symptoms and consequences of such societies. There are more and more aged people and even the ratio of the elderly is constantly increasing. Because of the deformation of the structure of the society the ratio between active and inactive people has been decreasing. Besides, there are more and more ill old people, not to mention that the ratio of women increasing between the elderly. Therefore, we encounter more and more serious problems and tensions in our societies regarding share of work, roles in the society, moreover, concerning pensions, health and social care as well.

In order to solve these problems the European societies have been developing strategies and programs e.g. the White Book or in Hungary the National Strategy of Aging Matters. The European Year 2012 with the motto: 'Active Ageing - Solidarity between Generations' would like to help reach an 'age-friendly Europe' by the year of 2020. The problems are pressing; nevertheless, we can hardly see 'the light at the end of the tunnel'. Nevertheless, solutions exist. This article is about a couple of these solutions as well.
\end{abstract}

Key words: aging societies, active aging, solidarity between generations

DOI: $10.19055 / \mathrm{ams} .2013 .4 / 11 / 1$ 
„A lejtőn lefelé menet legalább olyan munkás,

mint a felfelé kapaszkodás, bár nem mindig olyan élvezetes"

A világon sok minden öregszik, ahogyan az ember vagy például a gumi is, $\mathrm{s}$ időnként akár egy társadalom is elöregedhet. Sokan ismerik az emberi öregedés jellemzőit, de kevesen tudják, mi is az, mikor egy társadalom öregszik el. Jól tudjuk, hogy az ember, miután megöregszik, öregkorában bizony nem mindig kellemes változásokkal szembesül. Ehhez hasonlóan a társadalom elöregedése is negatív tendenciákat vetít elö. S ma már nem farkast kiáltunk...

\section{Öszülö társadalmak}

\section{A társadalom elöregedéséről}

Egy társadalom akkor fenntartható, ha szerkezete közelít egy ideális piramis szerkezethez (1. ábra). Ekkor többen születnek, mint az elötte született gyermekek, akik többen vannak, mint elöttük a fiatalok, akik többen vannak, mint a felnőttek, akik többen vannak, mint az idősek, akik szintén nagyobb számban találhatók az aggoknál (mellesleg a férfiak száma mindig közel megegyező a nőkével, minden korosztályban). Így biztosítható a társadalom folyamatos fejlödése, fenntarthatósága.

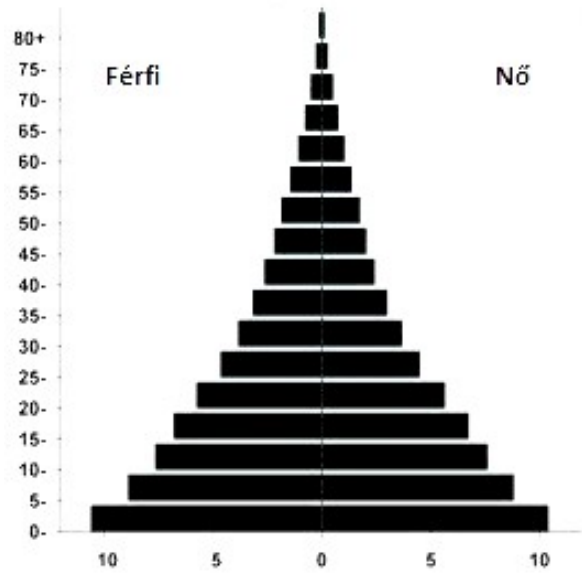

1. ábra. Egy társadalom ideális szerkezete. 
Mit látunk azonban az utóbbi néhány évtizedben Európa-szerte, köztük hazánkban is?

Egyre nagyobb számban vannak ezekben a társadalmakban idös emberek.

Az időszámítástól egészen a 19. századig az emberek átlagéletkora valahol 3035 év körül mozgott. Az elmúlt 200 évben azonban megduplázódott, ma már ez 75-85 év körül van az európai országokban (köztük Magyarországon is). Nem csoda tehát, ha azt észleljük, hogy nőtt az idős emberek száma, hiszen egyre tovább élnek az emberek, s így megérik az idős kort is. Azonban nem csak számszerü növekedés tapasztalható, hanem aránybeli eltolódások is.

Nö az idős emberek aránya is egy társadalmon belül.

Nem volna tehát semmi probléma az idősek számának növekedésével, ha nem kísérné ezt a társadalom szerkezetének torzulása, például a születések számának visszaesése miatt. Azonban, mint ahogyan azt a 2. ábrán is látjuk, a kezdetben még ideális szerkezet a 19. század végén (A) már torzul az 1930-as évekre (B).

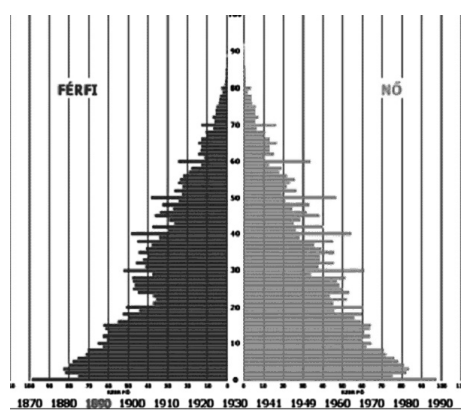

A

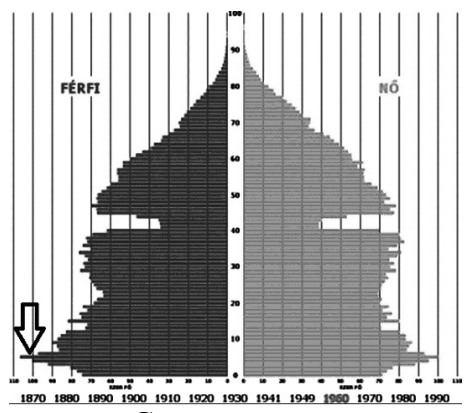

$\mathrm{C}$

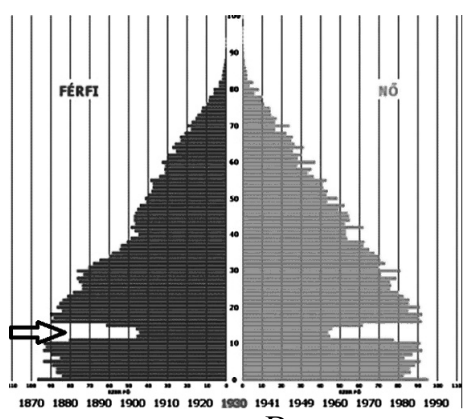

B

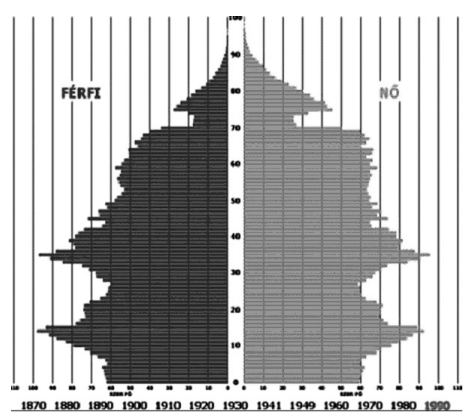

$\mathrm{D}$

2. ábra. A társadalmi szerkezet változása az elmúlt évszázadban.

$\mathrm{A}=$ XX. századelő; $\mathrm{B}=1930 ; \mathrm{C}=1960 ; \mathrm{D}=1990$. 
Itt megfigyelhetjük az első világháború okozta „,sebhelyet” (nyíl), míg a C ábránál már látjuk, hogy a „Ratkó-korszak” kicsit visszafordította az elötte megjelent születás-szám visszaesést. A mai magyar társadalom helyzetét jól mutatja az utolsó (D) ábrarész, ahol is látjuk, hogy a Ratkó-korszak után folyamatosan visszaesett a születésszám, s a mai magyar állapotok távolról sem hasonlítanak az ideálishoz. Ez már egy elöregedő (sőt elöregedett) társadalom szerkezetét mutatja.

Egyre kevesebb eltartóra egyre több eltartott jut.

Amint a 3. ábrán is látható, az idősek arányának emelkedésével párhuzamosan a fiatalok arányának csökkenését észleljük. Így lesz egyre kevesebb azok száma, akik aktívak és keresnek, s egyre nagyobb azok száma, akik már nem keresőképesek és „eltartásra” szorulnak.

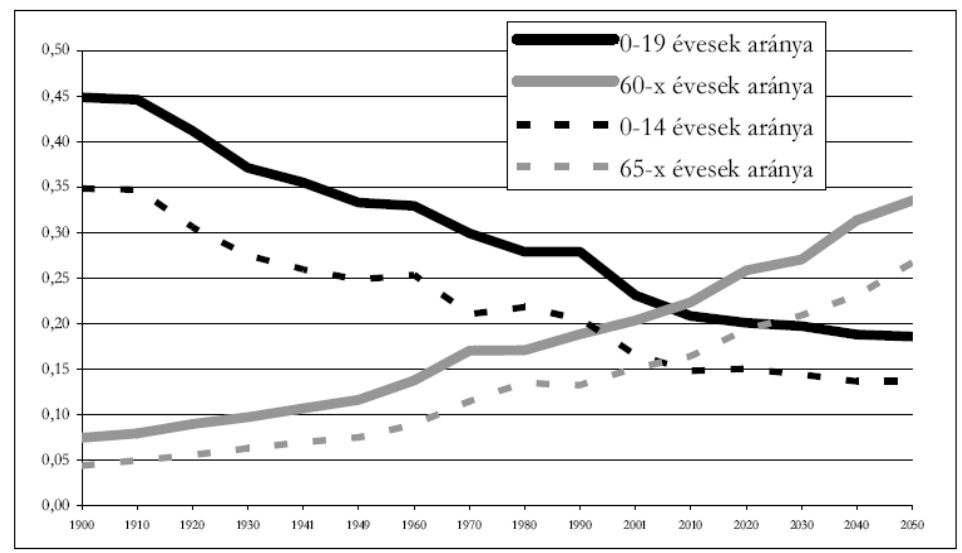

3. ábra. Aránybeli változások különböző korosztályoknál.

Egyre több beteg idös ember van.

$\mathrm{S}$ ha mindez nem volna elég, további gondok is adódnak - kicsit paradox módon pozitív változások következményeként. Míg az elmúlt évszázad elején a legnagyobb számban az emberek fertőző betegségben és tüdőgyulladásban haltak meg, addig ma a magyar lakosság több mint fele szív és érrendszeri bajai miatt hal meg. A halandóság alapirányzatának ilyetén megváltozásának a vonzata az, hogy míg a múlt évszázad elején a betegek vagy meggyógyultak, vagy meghaltak, manapság a kardiovaszkuláris betegek akár évtizedekig is élhetnek. 
Az idős emberek döntö többsége a női nemhez tartozik.

Ha megfigyeljük a nemek közötti különbségeket, akkor azt látjuk, hogy a nök átlagéletkora mintegy 10 évvel magasabb a férfiakénál. Ahogy haladunk előre a korban, egyre nagyobb arányban lesznek a hölgyek, s értelemszerüen a férfiaké csökken. Ez azt jelenti, hogy a családok férfi tagja már nem él a nejével, de az egyedül még tovább él.

\section{A következmények}

Amint azt sejteni lehet, mindezen társadalmi változások következményekkel járnak. De melyek is ezek?

\section{Egyre nagyobb társadalmi feszültségek keletkeznek.}

Sajnos, az elmúlt időszak „piramis - játék” típusú nyugdíjrendszere nem teszi lehetővé, hogy a kevesebb kereső által termelt kevesebb bevételek finanszírozzák az egyre növekvő számú eltartottat. Ideális szerkezetü társadalom esetén ez nem gond, hiszen egyre többen lesznek a keresők, s a náluk kevesebb eltartottat minden gond nélkül el is tartják. A megváltozott szerkezetben azonban csak akkor müködne a rendszer, ha mindenki saját nyugdíját megteremtette volna már meg előzőleg. S mint jól tudjuk, nem ez a helyzet. A bevételek csökkenése nem tud lépést tartani a növekvő igényekkel. Így nem csoda, hogy fokozatosan csökkennek a nyugdíjak (először csak a 13. havit kézbesítették a tárgyhóban... majd már csökkentésröl kellett dönteni). Ez eladdig vezet, hogy összeomlik a nyugdíjrendszer. Kiváltképp, ha megjelenik a Ratkó-korszak nemzedéke, s tartja a kezét jól megérdemelt nyugdíjáért.

Gondok jelentkeznek a nyugdijellátásban.

Mivel egyre több a beteg idős ember, egyértelmü, hogy a betegellátás terén is gondok jelentkeznek. Ha figyelembe veszünk olyan tényeket, miszerint az idösek gyógyszerigénye 10-szer nagyobb a felnőtt korosztályénál, s hogy kórházi ellátásuk gyakorisága meghaladja a felnőttek 12-szeresét, akkor könnyen beláthatjuk, hogy a mai magyar egészségügy tulajdonképpen idős-egészségügy. Nem csoda tehát, hogy omladozik az egykor jobb napokat látott hazai egészségügy.

Gondokjelentkeznek az egészségügyi ellátásban.

A társadalom gondjainak növekedésével párhuzamosan (a rendszerváltás által még egy lapáttal rátéve) az állam egyre jobban próbál kihúzódni „,kötelezettségei” alól. Ez megnyilvánul a szociális ellátások megnyirbálásában is. Noha nem 
több mint 2-4\%-át látja el az állam központilag az összes nyugdíjas korúnak, manapság már ez is túl nagy teher a társadalom számára, de folyamatosan csökken az egyéb szociális ellátásra rendelkezésre álló lehetőség is. A szocializmus nyíltan deklarált ellátó funkciója egyre jobban a svéd modell felól az amerikai felé tendál; azaz az állam helyett mindenkinek magának kellene gondoskodnia önmagáról. Lehet „kicselezni” a kötelezettségvállalást (pl. az időskorú szülőket ezentúl törvényileg köteles ellátni gyermeke), de ettől a gondok nem fognak megoldódni, csak az állam rázza ki nyakából a terheket.

Gondok jelentkeznek a szociális ellátások terén.

Az Európai Unió - látván a kialakult helyzetet - megpróbál valamilyen formában ellene hatni a tendenciáknak. A később részletezendő megoldási stratégiák közül az idősebb nemzedék foglalkoztatását próbálja meg megnyújtani ,ajánlások" révén. Ehhez tartozik az is, hogy Magyarországnak folyamatosan emelnie kell az 50 év felettiek foglalkoztatási rátáját. A már amúgy is eldurvult helyzetre (magas és emelkedő a munkanélküliség) még ilyen „okos” intézkedések is rásegítenek. Az EU döntéshozóinak vajmi kevés fogalma van az Unió heterogenitásáról; azaz arról, hogy igencsak más-más gondok foglalkoztatják az egyes államokat, ha már csak a gyorsan haladók és a „kevésbé iszkoló” államokat is hasonlítjuk össze, s ezzel párhuzamosan a megoldási stratégiák is eltérőek lehetnek. A fiatalok vs. idősek foglalkoztatása kérdése kapcsán egyre jobban erősödnek az ,ageizmus" hangjai, azaz:

Gondok jelentkeznek a munkamegosztás terén.

Néhány - de nem az összes - következményét megemlítettem fent a társadalmi elöregedésből fakadó problémáknak. Emellett számos másikat is lehetne említeni, esetlegesen kisebb horderővel. Azonban már a fent említettek megoldása is meglehetősen nehéz feladat elé állítja az elöregedő társadalmakat (köztük a magyart is).

\section{Van-e megoldás?}

Ha az ember látja, hogy gond van, mindig megoldást keres annak elhárítására. Így van ez az ember öregedésével, de a társadalom elöregedése kapcsán is. Igen sürgető (lenne) a gondjaink megoldása, hiszen a társadalmi elöregedés nem most kezdődött (jó évtizedekkel előbb), s tudjuk, minél hamarabb találunk megoldásokat, annál kevésbé szenvedjük meg a következményeket. Amennyiben nem teszünk semmit a társadalom elöregedéséből fakadó gondjaink orvoslására, sok más tényezőhöz hasonlóan (pl. háborúk, járványok, stb.) ez is elvezethet a nem- 
zetromlás, sőt -elfogyás víziójához. Ha ugyanis nem teszünk semmit, automatikusan a nulla (taigetoszi) megoldás lép életbe; azaz, a társadalom (s főleg az idősek) magára marad(nak) ,hadd hulljon a férgese” következményekkel. Ez ugyan meglehetősen cinikus megoldás, de jól jellemzi a mai magyar valóságot.

Az Európai Unió többi országa már jóval ezelőtt realizálta az eseményeket. Hathatósan nem tett ugyan ellene, de igen sok ,stratégiát”, (fehér) könyvet (Fehér könyv, 2012; IH 1), programot (IH4) gyártott, szervezeteket hozott létre, hogyan kellene megoldani a gondokat (emellett jobb anyagi lehetőségeik révén többet is tehettek a gondok orvoslására). Mindezek azonban nem oldották meg teljes mértékben az államok gondjait, ahogy Magyarországét sem, hiszen bár nálunk létezik egy Idősügyi Nemzeti Stratégia (INS, 2009), van Idősügyi Tanács is és egyéb tervek és programok, de minden annyit ér, mint ami belöle megvalósul. Anélkül, hogy tudományos igényességgel analizálnánk ezen programok és szervezetek munkáját, teljes nyugalommal kijelenthetjük, hogy mindezek csak írott malasztok maradtak, illetve a felállított szervezetek nem felelnek meg funkcióiknak. Nem csoda ez, ha látjuk, hogy a terveknek nincs cselekvési programjuk, azaz a terveket nem követik tényleges tettek. S akkor még azt sem említettük, hogy ezen „stratégiák” enyhén szólva sem teljesek, illetve rosszul határozták meg a problémák és megoldások fontossági sorrendjét. S így ilyenkor még a krónikus pénzhiányra sem lehetne hivatkozni...

Van-e tehát megoldás, s hogyan kellene hozzáfogni?

Mi is a legfontosabb ahhoz, hogy egy ember - vagy a belölük szerveződött társadalom - el tudja látni a funkcióit? Az elsődleges feltétel, hogy egészséges legyen. Erről sokszor hajlamosak vagyunk megfeledkezni, természetes alapállapotnak vesszük. Mindez csak akkor válik fontossá, ha baj van az egészséggel. $\mathrm{S}$ ez az, ami a mai idős korosztályt jellemzi, azaz igen sokan szenvednek különböző (krónikus) betegségben (Székács és mtsai, 2011). Így sem a társadalom számára nem lesznek hasznosak (pl. önkéntesség, saját családjuk segítése, stb.), s saját jól megérdemelt nyugállományukat sem tudják (maradéktalanul) élvezni. Ha a jelenséget azonosítottuk, könnyebb a megoldást megtalálni.

\section{Az elsődleges megoldás tehát az emberek egészségének megőrzése, illetve betegségük esetén egészségük visszaállítása.}

Milyen megoldások vezethetnek ide?

A kormányzati közgondolkodásban természetesen az egészségügy helyzetének javítása tünik megoldásnak (noha mind a mai napig nem realizálták, hogy az egészségügy az idősek egészségügye). Pumpáljunk még több pénzt az egészség- 
ügybe - vagy rosszabb idők esetén próbáljuk fenntartani az előbbi állapotokat. S látják, hogy ez nem megy. Nem, hogy az elötte levő állapotokat nem tudják fenntartani, de fokozatosan romlik a szolgáltatás (még ugyanannyi, vagy esetleg több pénz esetén is). Egyenes következménye ez annak, hogy egyre több beteg idős ember van, akit el kell(ene) látni.

Ilyenkor - néha - felmerül, hogy a helyzet további romlását (vagy a későbbi javulását) a megelőzéssel lehetne segíteni (Semsei, 2011; Székács és mtsai, 2011). Ezt ugyan - elvileg - mindenki tudja, de a gyakorlatban nem valósul meg. Vannak ugyan szürőprogramjaink (lásd pl. a tüdőszürést, mellyel vissza lehetett szorítani a TBC-t, melyről a múlt század eleji Magyarország elhíresült; vagy a mellrákszürést, mely révén az európai átlaghoz közelítünk az esetleges más vonatkozásban meglévő néhány száz százalékos rosszabbi állapottól eltérően). Nincsenek azonban szürőprogramjaink, az időseket legjobban érintő szív- és érrendszeri problémák szürésére. Pedig ma Magyarországon ez a népbetegség, mint hajdan volt a TBC. Egy jó prevenciós program sokat segíthetne a bajok orvoslásában. Hogy nem most hatna, majd csak egy-két (néhány) évtized elteltével jelentkeznének az eredmények? Igen, a prevenció sajátossága már csak esetenként ilyen. Nem lehet (sajnos) a néhány éves kormányzati programokban „lobogtatni”, hogy milyen sikereket értek el ezen a területen. Ezért tehát nem is csinálják... Pedig közgazdaságilag is bizonyított, hogy a prevenció még olcsóbb is, mint a már jelentkező betegségek kezelése (és akkor még nem beszéltünk egyéb járulékos hatásokról, mint a munkából való kiesés, stb.).

Kellene tehát egy jól müködö program a sziv és érrendszeri betegségek szürésére, prevenciójára.

S ha további „eretnekségeket” akarunk említeni, megjegyezhetnénk azt is, hogy még a prevenciónál is lenne egy fontosabb megoldási lehetőség: $\mathrm{s}$ ez az ismeretek terjesztése (Semsei, 2011). Néha egy két hozzáértő megemlíti, hogy ha a gerontológia eredményeit (Mi is az? Ha a balneológia a bálnákról szól, akkor a gerontológia miről is? - kérdeznék az ,illetékesek”...) sikerülne a gyakorlatba átültetni, akkor (szinte instant módon) az átlagéletkort akár 1-2 évtizeddel is meg lehetne hosszabbítani (ami természetesen együtt járna egy jobb egészségi állapottal is). S ez még a prevenciónál is költséghatékonyabb lehetne.

A legfontosabb azonban a gerontológiával és egészségmegörzéssel kapcsolatos információk terjesztése lenne.

Ha megnézzük tehát e rendelkezésünkre álló lehetőségeket, az egészség megörzésére, illetve visszaállítására, akkor (fontossági sorrendben) a következőket kapnánk: 


\section{Ismeretterjesztés, oktatás}

\section{Prevenció}

\section{Gyógyítás-ápolás}

\section{Rehabilitáció.}

Mire gondolunk, mikor az ismeretek terjesztésének fontosságára gondolunk az egészség megörzésének, illetve visszaállitásának kérdésében?

Anélkül, hogy teljesség igényével beszélnék erről (a nyilvánvaló terjedelmi korlátokra tekintettel), néhány vonatkozását megemlíteném (Semsei, 2011).

Még a gyermekek számára is fontos lenne (ami elsőre nem tünik egyértelmünek), hiszen ők azok, akik a legtöbbet tehetik egészségük megőrzéséért (nyilvánvalóan minden korosztály tehet, de a korral előrehaladóan egyre szükülnek a lehetőségek). S azt is meg kell tanulniuk, hogy „ha szerencséjük lesz, ők is megöregednek" (lásd még pedagógia - gyermeknevelés). Ha más eredménnyel nem is, de azzal járna, hogy az ageizmus (egyes társadalmi rétegek, csoportok negatív attitüdjei és ezek megnyilvánulásai az idősekkel szemben) mérséklődne, s a generációk közötti szolidaritás megvalósulna, már így is igen nagy eredménynek tekinthetnénk a gyermekkori gerontológiai ismeretek terjesztését. $\mathrm{S}$ ha a gyermek nem tesz egészségének fenntartásáért, felnőttként sem fog, s idősként pedig beteg lesz.

A felnőttek ismereteinek gyarapítása (andragógia) is igen fontos, hiszen még mindig vannak lehetőségeik egészségük megőrzésére, egyes folyamatok meggátlására (esetenként visszafordítására) is (Jászberényi, 2011). Ehhez hozzátehetnénk az egész életen át tanulás fontosságát (Life Long Learning), mely nem csak az ismeretszerzés fontosságában nyilvánul meg (pl. a felnőttkori munkavégzés ismereteinek birtoklására a munka megtartásáért), de aki egész életében tanul, szellemi funkcióit is könnyebben megörzi. Kevesebb demens (Alzheimeres) ember - kevesebb költség, több haszon. Meg kell még említeni azt is, hogy míg a fiatalok esetében az állam gondoskodik róla, hogy beilleszkedjenek a társadalomba, a munkamegosztásba (lásd oktatás), addig a felnőttek kezét elengedi, mikor már nincs rá szüksége (,a mór megtette kötelességét - a mór mehet...”). Fontos lenne azonban felkészíteni a nyugdíj elötti generációt, hogy mire számítson nyugdíjba vonulásakor, $\mathrm{s}$ a jelentkező problémákra milyen megoldásokat találhat. Ezzel (is) igen nagymértékben lehetne a „leendő idősek” egészségi és szociális helyzetén javítani.

Emellett a harmadik korosztály ismeretszerzése (gerontagógia) is pozitív hozadékú (Jászberényi, 2011; Dobos és Szalkai, 2011). Még akkor is, ha egyes preven- 
ciós formák (az elsődleges és esetenként a másodlagos) már korlátozottabb hatásúak lehetnek, de ha az idős ember csak azt tanulná meg, hogy függésének mértéként hogyan tudná a lehető legkisebbre csökkenteni, már mindenki jól járna (pl. hogyan menedzselhetem magamat esetleges betegségem esetén, hogy ne szoruljak, vagy minél kevésbé szoruljak másokra). Emellett azonban a megelőzés még mindig igen nagy jelentőségủ lehetne. Ha az idős ember például azzal tisztában lenne, hogy egy adott kor felett tilos elesni, akkor kb. 15\%-uk nem halna bele egy banális csonttörésbe. $\mathrm{S}$ a példák szinte vég nélküliek. Az időskor egyéb ismeretszerzése is jelentős, hiszen akár reguláris, vagy irreguláris képzés keretén belüli ismeretek elsajátítása is része az idősek életminőségének fenntartásában, javításában (pl. ha az idôs ember is megtanul számítógépet használni).

\section{S hogyan is állunk ma a gerontológia oktatásával és ismeretterjesztésével?}

A helyzet bizony távolról sem mondható megoldottnak - magyarul: nagyon roszszul (Semsei, 2012). Sporadikusan és esetenként ad hoc jelleggel folyik ilyen oktatás a hazai intézményekben (szinte egy kézen meg lehet számolni, hol). A legelörehaladottabb (egyedüli komplexitással) a gerontológia oktatása a Debreceni Egyetemen, annak Egészségügyi Karán:

Felsőfokú szakképzés (előkészületben)

BSc:

Szociális munka (nappali \& levelezö)

$>$ Egészségügyi képzés ( $\mathrm{n} \& \mathrm{l}$ )

$>$ Gyógytornász (magyarul és angolul; Népegészségügyi Kar)

MSc:

Szociális munka (n \& 1$)$

$>$ Egészségügyi képzés ( $\mathrm{n} \& \mathrm{l})$

$>$ Gerontológia MSc szak (előkészületben)

* Posztgraduális oktatás $(\mathrm{PhD})$

$>$ Általános Orvoskar - oktatás

$>$ Egészségügyi $\mathrm{Kar}-\mathrm{PhD}$ fokozat

Posztgraduális képzés (Szakirányú továbbképzés)

$>$ Alkalmazott szociális gerontológia

> Alkalmazott preventív gerontológia (előkészületben)

Nyilvánvaló (a szakemberek számára) a társadalmi elöregedés és az abból fakadó problémák jelentősége, ugyanakkor egyetlen egyetem foglalkozik ilyen komplexitású gerontológiai képzéssel (nem csoda ez, hiszen az Oktatási Állam- 
titkárságnál nem találni egy embert, aki nem hogy gerontológiai konferencián elő tudna adni a témában, de egyáltalán tudná, hogy mi is az...).

$\mathrm{S}$ akkor még nem említettük az egyéb ismeretterjesztő formákat, melyekre szintén igen nagy szükség lenne. A Harmadik Kor Egyeteme Miskolc (IH, 3), vagy a Nyugdíjasok Óbudai Akadémiája (IH, 5) üdítő kivétel ezen a területen, hiszen alig találkozunk ilyen ismeretterjesztési formákkal hazánkban. Csehországban például minden egyetemnek regulárisan (és államilag támogatva) van Harmadik Kor Egyeteme szervezete.

S ha már más országoknál tartunk, az Európai Unió létrehozott egy szervezetet: AGE Platform Europe (IH, 1; Magyar Gerontológia, 2012), mely segítséget nyújt az unió tagjainak a társadalom elöregedéséből eredő problémáinak megoldásához, bár hatásköre csupán ajánló és tanácsoló jellegü, DE esetenként hatása egészen az UNECE tagországok minisztereinek deklarációjáig vezetett $(\mathrm{IH}, 6)$. $\mathrm{Az}$ Európai Unió minisztériumai (Directorate General) közül ma már több is foglalkozik valamilyen formában az unió tagállamainak elöregedéséből fakadó problémák megoldásával, noha nincs egyedüli felelőse. Az EU-nak az a víziója, hogy az „Aktív idősödés - nemzedékek közötti szolidaritás” zászlaja alatt (The EU Contribution, 2011) 2020-ra egy idősbarát Európát alakít ki. Ezzel párhuzamosan Magyarországnak is rengeteg teendője lenne, a fent említett oktatási, egészségügyi vagy akár szociális területeken is (Csernáthné, 2011).

A cikkben említett jelenségek csak részben írják le a társadalom elöregedéséböl fakadó gondokat, ahogyan a javasolt teendők is csak egy részét képezik a megoldásoknak. Nem beszéltünk a társadalmi kapcsolatok torzulásairól sem (a munkamegosztás gondjai, nemzedékek közötti ellentétek, stb.) ahogyan nem történt említés számos más megoldási lehetőségről (pl. születések számának emelése, nyugdíj korhatár emelése, idősek bevonása, megtartása a munkában, stb.). Ezen munka célja az volt, hogy felhívja a figyelmet egy régóta meglévő jelenségre, mely igen erősen befolyásolja társadalmunk helyzetének alakulását, s ráirányítsa a figyelmet az egyes megoldási lehetőségekre.

\section{Összefoglalás}

Magyarország - mint a többi európai ország - őszülő (elöregedő) társadalom, annak összes ismérvével és következményeivel együtt. Egyre nagyobb számban vannak idős emberek az országban, sőt arányuk is folyamatosan növekszik. A társadalom szerkezetének torzulása következtében az aktív keresők és az eltar- 
tottak aránya is egyre romlik. Emellett egyre több beteg idős ember van, s az idősek között növekszik a nők aránya. Mindezek következtében egyre nagyobb társadalmi gondok és feszültségek keletkeznek a munkamegosztásban, a társadalmi szerepvállalásban, de a nyugdíjak, az egészségügyi és szociális ellátások területén is.

A fentiek megoldására az európai társadalmak megoldási stratégiákat és programokat dolgoznak ki, mint például a Fehér Könyv vagy Magyarországon az Idősügyi Nemzeti Stratégia. Az Európai Unió 2012-es éve az „Aktív idősödés - nemzedékek közötti szolidaritás" mottójával szeretné elérni, hogy Európa 2020-ra „idősbarát Európává” váljon. A tennivalók sürgetőek, a megoldások fényei viszont még mindig nem látszanak az alagút végén. Pedig lennének megoldások. Erről szól ez a közlemény is.

\section{Irodalomjegyzék}

1. Dobos L, Szalkai I. (2011): Az egészséges és aktív öregedés gyakorlata az Idősügyi Nemzeti Stratégiában. Magyar Gerontológia 12: 23-34.

2. Csernáthné KE. (2011): Az Idősügyi Nemzeti Stratégia szociális vonatkozásairól. Szociális szolgáltatások és az ehhez kapcsolódó Stratégiai Terv. Magyar Gerontológia 12: 50-54.

3. Fehér könyv: A megfelelő, biztonságos és fenntartható európai nyugdíjak menetrendje (2012): Európai Bizottság, Brüsszel, 2012.2.16.

4. Idősügyi Nemzeti Stratégia. Az Országgyülés 81/2009. (X.2.) OGY határozata.

5. Jászberényi J. (2011): Geronto-edukáció. Az idősoktatás helyzete és perspektívái itthon és a nagyvilágban. PrintX-Budavár Kiadó, Budapest. (ISBN 978-96386545-2-6)

6. Magyar Gerontológia (2012) 4. évfolyam 14. szám (ISSN 2062-3690; 20623682).

7. Semsei I. (2010): A gerontológia oktatása. Magyar Gerontológia 5: 4-15.

8. Semsei I. (2011): Hangsúlyok az Idősügyi Nemzeti Stratégia cselekvési programjában. Magyar Gerontológia 12: 3-14.

9. Semsei I. (2012): A gerontológia oktatásának mai helyzete országunkban. Magyar Gerontológia 16: 3-16.

10. Székács B, Kiss I, Regius O, Bakó Gy. (2011): Idősorvoslás hiánya az Idősügyi Nemzeti Stratégiában. Magyar Gerontológia 12: 34-50.

11. The EU Contribution to Active Ageing and Solidarity between Generations (2012): Luxembourg: Publications Office of the European Union. ISBN 978-92-79-25123-8, doi:10.2767/67267. 
12. Zöllei M, Bakó Gy, Semsei I. (2011): Oktatási kérdések az Idősügyi Nemzeti Stratégia keretében. Magyar Gerontológia 12: 14-23.

Internetes hivatkozások:

1. AGE Platform Europe: http://www.age-platform.eu/en

2. Fehér könyvek: http://europa.eu/documentation/official-docs/whitepapers/index_hu.htm

3. Harmadik Kor Egyetem (Miskolc): http://www.harmadikkoregyeteme.hu/alapitvany.html

4. Lisszaboni Stratégia: http://www.euvonal.hu/index.php?op=kerdesvalasz_reszletes\&kerdes_valasz_i $\mathrm{d}=1431$

5. Nyugdíjasok Óbudai Akadémiája: http://www.zskf.hu/nyugdijasok

6. Vienna Ministerial Declaration:

7. http://www.ngocoa-ny.org/events/regional-conferences/unece-ministerialconferenc.html

Dr. Semsei Imre: MTA doktora

Debreceni Egyetem Egészségügyi Kar, 4400 Nyíregyháza, Sóstói u. 2-4. 
